\title{
LANDSCAPE PAINTING IN EVALUATION OF CHANGES IN LANDSCAPE
}

\author{
JAN LACINA, PETR HALAS
}

Institute of Geonics of the CAS, v. v. i., Brno branch, Drobného 28, 60200 Brno, email: lacina@geonika.cz,halas@geonika.cz

Received: $22^{\text {nd }}$ June 2015 , Accepted: $19^{\text {th }}$ October 2015

\begin{abstract}
One of common methods of determining landscape change usually is to compare maps and photographic images of the same places in different time horizons. Landscape painting, which has a long and rich tradition in the Czech Republic, can be used similarly. Landscape-ecological interpretation of selected works by painters of the $19^{\text {th }}$ century - Julius Mařák, František Kaván and Antonín Slavíček was done in this paper. Some pictures of the Českomoravská vrchovina (Bohemian-Moravian highlands) by Josef Jambor from the mid- $20^{\text {th }}$ century were used for detailed comparative analysis to the level of habitats. We compared 80 landscape paintings and found that most of the painted sceneries have changed for worse.
\end{abstract}

Keywords: landscape painting, landscape ecology, maps, photographic images, comparative study, land-use changes, biodiversity

\section{INTRODUCTION}

Changes in land-use and in the character of the landscape are commonly determined through the comparison of maps, photographs, aerial photographs and in the last decade also satellite imagery of various time periods. Landscape painting can be used in similar way, as well as graphical descriptions of the landscape if they are realistic and detailed enough. Art of this kind has got a long and rich tradition in the Czech Republic. A landscape ecologist can compare the existing landscape with its shape and form long in the past based on large number of art pieces from various areas (Lacina, 2009; 2011). It is necessary to take care searching for the locations of old pictures in the landscape.

Those artworks created long before photography was invented and even before the first military mapping took place are of the upmost importance. They include mainly vedute, highly detailed, usually large-scale paintings of cityscapes that are often the only topographically relatively accurate documentation of the state of the landscape several centuries ago. As an example, an engraver of European importance - Václav Hollar (16071677) - captured hills and extensive vineyards nowadays long developed in his vedute of Prague in 1635. Vedute of Brno are similar, e.g. the one of Jan Willenberg from 1593 - the dominant vegetation elements of the close proximity of the town walls used to be vineyards there, too. 
The projection of real landscape in paintings originated in the Netherlands in the $17^{\text {th }}$ century. For example Jacob Ruisdael (1628-1682) often painted solitary old oaks on sandy dunes in the middle of highly cultivated plain. The main period of European landscape painting came in the $19^{\text {th }}$ century with numerous over-reaches into the $20^{\text {th }}$ century. Landscape painting was progressing from romantics to realism during the $19^{\text {th }}$ century - i.e. from depicting romantic landscapes, mainly mountainous ones (even Czech painters enjoyed painting of Alpine peaks and lakes or at least those of the Šumava Mts.) towards the more common ones including rolling land and lowland. The manuscript of the painters gradually loosened especially under the influence of French Barbizon landscape painters. Several landscape painting schools took turns on the Prague Academy of Visual Art since the $19^{\text {th }}$ century with several breaks. These included schools of Karl Postl, Antonín Mánes, Maximilan Haushofer, Julius Mařák, Otakar Nejedlý. They tutored, with the contribution of visual art abroad (Munich, Vienna, Düsseldorf, Paris and countryside Barbizon) tens of representatives of Bohemian and Moravian landscape painters. Other influential landscape painters studied even outside specialised landscape ateliers. Let's mention a few of the Czech landscape painters from the $19^{\text {th }}$ century whose creations can be looked at by ecologists nowadays and help to consider the real landscape: Bedřich Havránek (1821-1899), Alois Bubák (1824-1870), Adolf Kosárek (1830-1859), Adolf Chwala (1836-1900), Antonín Chittussi (1847-1891) a Julius Mařák (1832-1899). Ladislav Mednyánszky (1852-1919) was an exceptional artist representing the Slovakian landscape painting.

Despite the fact that already A. Chittussi (in Dvoŕák, 1954) said that a painter is not a photographer and despite various painting movements, landscape painting with sufficient number of realistic elements, allowing for comparison with the reality, continued in the $20^{\text {th }}$ century. The work of František Kaván (1866-1941), Antonín Slavíček (1870-1910), Jindřich Prucha (1886-1914), Jan Kojan (1866-1951), Oldřich Blažíček (1887-1953), Josef Jambor (1887-1964), Otakar Kubín (1883-1969), Vojtěch Sedláček (1892-1973) and Jan Trampota (1889-1942) can be used for comparison analysis.

The aim of this work is to show that perception of good quality landscape painting (not obtrusive kitches!) does not have to be only an aesthetic experience, but a landscape ecologist can also find many specialist pieces of information and can expertly interpret the landscape painting.

\section{MATERIAL AND METHODS}

Photographs of landscape paintings of Bohemian and Moravian artists from the $19^{\text {th }}$ and the first half of the $20^{\text {th }}$ century were taken in galleries of visual art (Horácká galerie in Nové Město na Moravě, Jambor's House in Tišnov) as well as in private collections. Another source for comparison were colour reproductions from art monographs. An emphasis was put harmonious cultural landscape while choosing individual paintings. The exact spot of the painter's view was located using maps while the accurate localisation of the painting was done through, often labourious, search in the field. After that a photograph was taken, representing the painter's field of view. In case there were new landscape elements in the view (buildings or trees), the photograph was taken from the nearest free location. Apart from the overall view, pictures of half-views and details were also taken. These helped to document the changes in landscape in the way of landscape structure mosaic as well as species composition of the vegetation cover. 


\section{RESULTS AND DISCUSSION}

A real treat for ecologically orientated viewer is the work of Julius Mařák (1832-1899). Not his monumental pictures of some selected Bohemian and Moravian localities for the National Theatre where the depicted objects are deliberately idealised and dramatized, but his forest interiors and individual woody species. The cycle of 13 coal drawings, called Austrian woodland characters (1878) is unique. He captured the woodland vegetation zonation of the then monarchy from oaks and hornbeams in the lowest altitudes $\left(1^{\text {st }}\right.$ vegetation zone according to Zlatník, 1963) all the way to pines and dwarf mountain pines of the tree line ( $8^{\text {th }}$ vegetation zone). The highlight of Maŕák's work is represented by a related large twin-canvas of Šmava primeval forest in the sun (1892-1897) and Šmava primeval forest in the storm (1891-1892) radiating the dynamics of mountain natural woodland where the fir-beech forests and climax spruce growths meet.

One of the great merits of Julius Mařák is the fact that he taught numerous extraordinary artists during his time in the Prague Academy of Visual Art between 1887 and 1899. They were trying to capture the reality of various Czech landscapes in the open air. These artists include František Kaván (1866-1941) whose very extensive artwork includes the painting The Iron Mountains from The Golden Brook in Třemošnici (1895). This oil-painting is often reproduced as a typical representation of the classical Czech landscape full of ease. When studying the foreground of the picture with greater care, we realise that the artist probably incidentally captured the wide flood-bed created during the catastrophic floods in Bohemia in 1890. Five years after the disaster, the catastrophic impacts are still obvious on the banks. The vegetation composition is dominated by thistles (likely Carduus crispus) and young woody plants are completely missing, probably because of the effects of selective cattle grazing. This speculation is confirmed by an even more detailed interpretation of the same landscape segment from the same period by Kaván's schoolmate and friend Bohuslav Dvořák (1867-1951) in the painting The Iron Mountains (1895).

Antonín Chittussi (1847-1891), born in Ronov upon Doubrava, learnt from French Barbizon landscape painters and painted in the open air in France as well as in his native landscape. His greatest work is represented by the oil-painting "From the Valley of the Doubrava" (1886). It is a segment of pasture in the rocky valley of the river with solitary trees. The architect Ladislav Žák in his nowadays inspirational book "Obytná krajina" (1947) (Livable Landscape) utilised Chittussi's painting as a warning demonstration of the way our landscape will look like should the expansion of human civilisation continue. The dramatic change luckily has not happened although it is not possible to find the angle of view Chittussi captured. The slopes of the Doubrava cutting (the so called Chittussi's Valley in the Natural Park of the Doubrava) are continually covered with woody vegetation. In addition to that it is possible that the artist composed his picture from several angles of view. Once the grazing ceased, young woody vegetation natural seeding as well as afforestation occurred here as well as in numerous other river valleys. The populations of heliophilous species were outcompeted.

An exceptional personality of the Czech landscape painting is Antonín Slavíček (18701910), also a graduate of the Mařák's landscape painting school, but inspired mainly by the work of A. Chittussi and almost approaching impressionism in his concepts. His influence was most obvious in 1903-1905 in Kameničky on the foothills of the Žd'ár Hills and the Iron Mountains. Despite the fact that the artist admits in a letter to a friend in 1905 that "not even in a thousand paintings" could he embrace the "inner life of the people and the region"; he certainly managed to depict the landscape composition and the relationships between them better than others. The popular painting U nás v Kameničkách (1904) (At ours in 
Kameničky) can even be considered as a kind of imaginary illustration of the scientific definition of landscape sphere as a meeting point of the blending of the Earth's crust with the landscape relief, hydrosphere, the lower section of atmosphere, paedosphere, biosphere and socio-economic sphere. Exactly this kind of complex yet beautiful union is shown in the above mentioned painting, capturing a segment of a simple, mostly agricultural pasture land with a row of trees, a figure of a woman with cows and an amazing Slavíček-specific sky reflected together with the trees in a small pond. It is very pleasant to find out that a very similar view can still be found on the edge of the village of Kameničky nowadays, including the species richness of meadows under the Volák's Hill where an extensive botanical research of the meadows carried out by the Botanical Institute of the Academy of Science of the Czech Republic (AVCR) took place.

"Only a very few things testify the way of our thinking as convincingly as the comparison of the former pictures of the Bohemian and Moravian landscape in the $19^{\text {th }}$ and $20^{\text {th }}$ century with its appearance nowadays" - as has been written by the former Minister for Environment of the Czech Republic, Mr Ivan Dejmal, for the poster advertising the art exhibition called "The appearance of our country - our home landscape" (Dejmal, 2001). The exhibition did not; however, allow for the comparison between the historic landscape paintings and the current appearance of the landscape. Only a set of landscape paintings of several generations of the Czech landscape painters - in a superb selection of works - were exhibited in the Theresian Wing of the Prague Castle. It is common to find at least the location of each painting, with various accuracy, in catalogues accompanying landscape painting exhibitions nowadays.

In the Czech Republic this can be seen for example in the localization of some pieces of A. Chittussi (Prahl, 2012), while in painting-wise much frequented Brittany there was a book with detailed maps of landscape paintings of numerous artists published (Anonymus, 1997). An interesting landscape painting exhibition was the "Two landscapes. Picture of Slovakia: the ninetieth century vs. these days" in the Slovak National Gallery in Bratislava, accompanied by an extensive catalogue (Čičo, ed. 2014). However, more than the comparison of the state of certain landscapes in the $19^{\text {th }}$ century and now, this was an attempt to confront the very different ways of depicting the landscape. Current way of doing so has little utilizable value for landscape ecologists.

A unique example of the comparison of historic paintings with the current state can be seen in the Podyjí National Park. An extensive set of works representing the romantic valley landscape, painting-wise very frequented predominantly in the $19^{\text {th }}$ century - is located in the collections of the South-Moravian Museum in Znojmo. In seven individual cases there was an identification photograph added, depicting the state of the current valley of the River Thaya (Frecer, 2009). A comparison of lithography by W. E. Knippel in his Panoráma $z$ Landeku shows near-natural state of the water meadow landscape of the River Oder in 1850 with a recent photography of the Ostrava industrial agglomeration was published in a monograph on deep coal mining and its impact on the environment (Martinec et al. 2006). The authors of this contribution (Lacina, 2013; 2014; Lacina \& Halas, 2013; Lacina, Ptáček, Halas 2014, 2015) are devoted to the comparison analysis of the Czech landscape paintings from the Bohemian-Moravian Highlands, mainly by Josef Jambor in its Moravian part but also other artists with the over-reach into Bohemia. There is a project (ARTOPOS, http://www.artopos.net/) focused on the comparison of landscape paintings with the present state of painted landscape currently running. Several authors from abroad also study landscape painting and its comparison to the real landscape, amongst them P. Machotka (2014) focussing on the work of Paul Cézanne. He managed to identify tens of locations that 
Cézanne used for his work. His view; however, does not provide the landscape-ecology insight because he was comparing the artwork from the position of an art psychologist.

The extensive work of Josef Jambor, born in Pohledec by Nové Město na Moravě (18871964) captures in hundreds of canvasses the harmonious cultural landscape of the thirties to the sixties of the $20^{\text {th }}$ century, mainly the landscape of the Žd'ár Hills. The work is, thanks to its realistic similarity, ideal for the landscape-ecological comparison analysis. The author himself (in Kafka, 1956) admitted, on the topic of the motivation for his work: "I wish, and will try hard to do so, to capture a lot of what is disappearing, losing its beauty due to the new industrial gadgets and methods"

We have chosen at least the painting called Rokytenské louky (The Meadows of Rokytno) from 1953 (Figure 1.) from the wealth of his artwork, through which it is possible to enter the phytocoelogical detail. It captures an extensive complex of wet meadows on the edge of Rokytno by Nové Město na Moravě in spring. Shallow depressions are still filled with the water from recently melted snowdrifts. In places where vegetation already started to grow, there is a display of Caltha palustris. In the sense of a typology of natural biotopes (Chytrý, Kučera, Kočí, 2001), it is possible to identify the T1.5 biotope of wet thistle meadow with reasonable accuracy. The vegetation of later aspects would have included Cirsium palustre, Bistorta major, Tephroseris crispa, Succisa pratensis, Parnassia palustris, Dactylorhiza majalis and others. The meadows were significantly degraded through amelioration of rivers and they lost a large number of herby species. During the mapping efforts for the NATURA 2000 European Union project, not a single segment of the former wet thistle meadow occurred in the area (Figure 5). The entire meadow complex falls into the category of biotopes strongly influenced or created by man - the X5 - intensively managed meadows. Only in the background the surveyors captured the natural biotope V1F - the macrophytic vegetation of eutrophic and stagnant water and the M1.1. - reed-beds of eutrophic stagnant waters. These are not visible from the painter point of view. Despite that it appears at the first glance that the overall scene setting hardly changed.

Fig. 1: Josef Jambor: Rokytenské louky (1953)

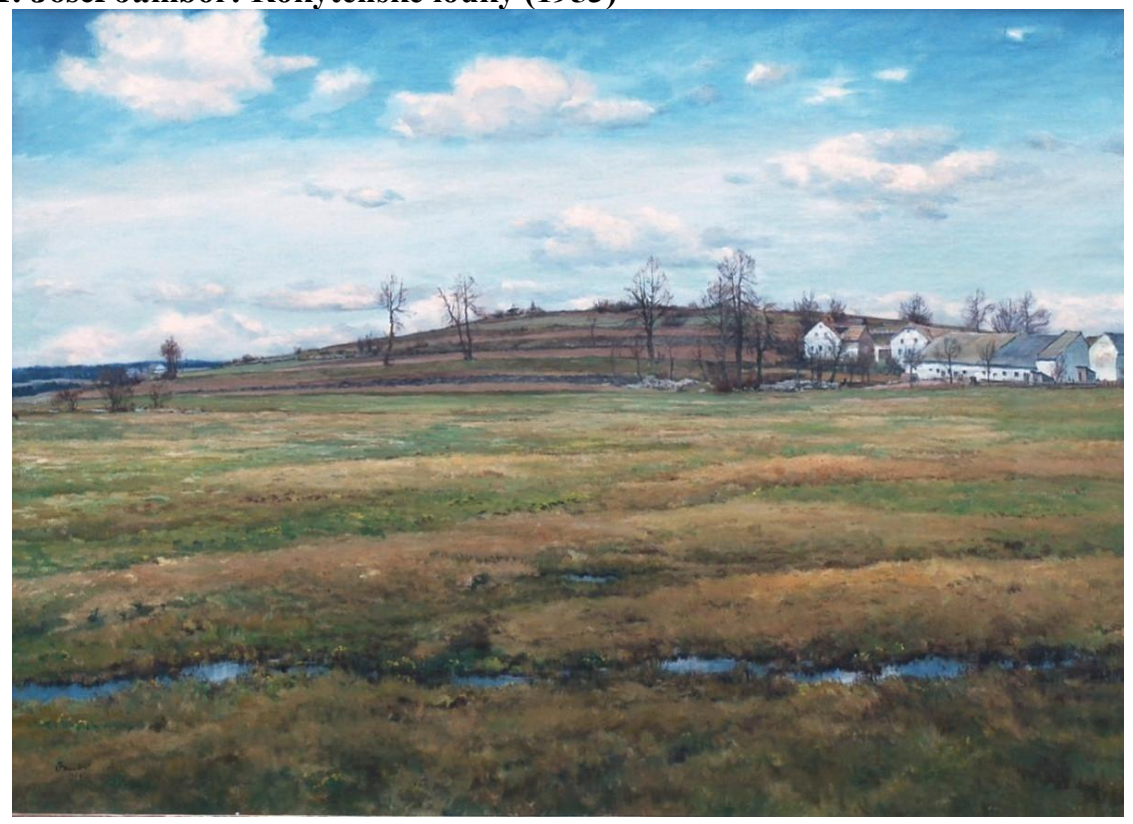


Fig. 2: Localisation of the picture (Josef Jambor: Rokytenské louky (1953)), utilizing a topographic map from http://www1.cenia.cz/

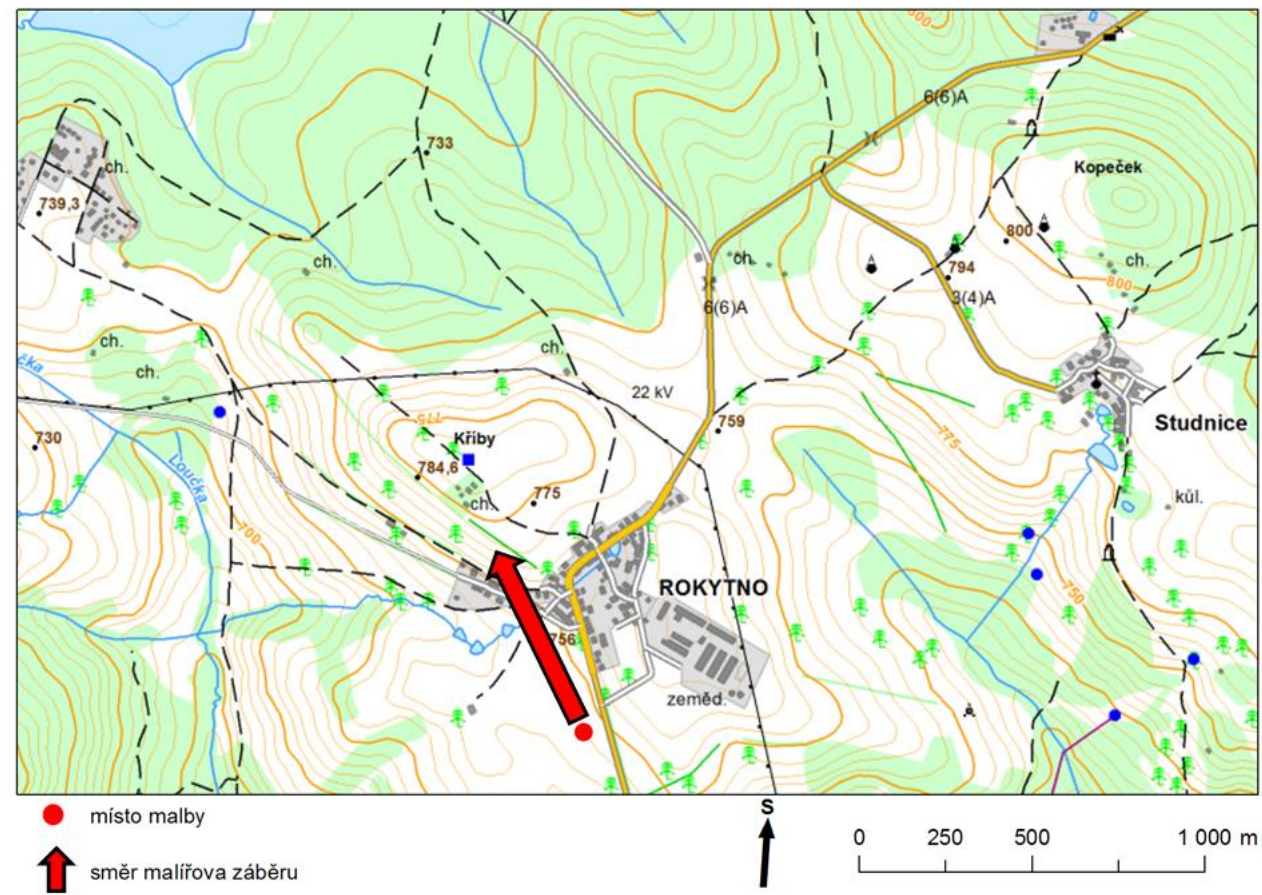

Fig. 3: The Meadows of Rokytno in 2012, photo by Josef Ptáček

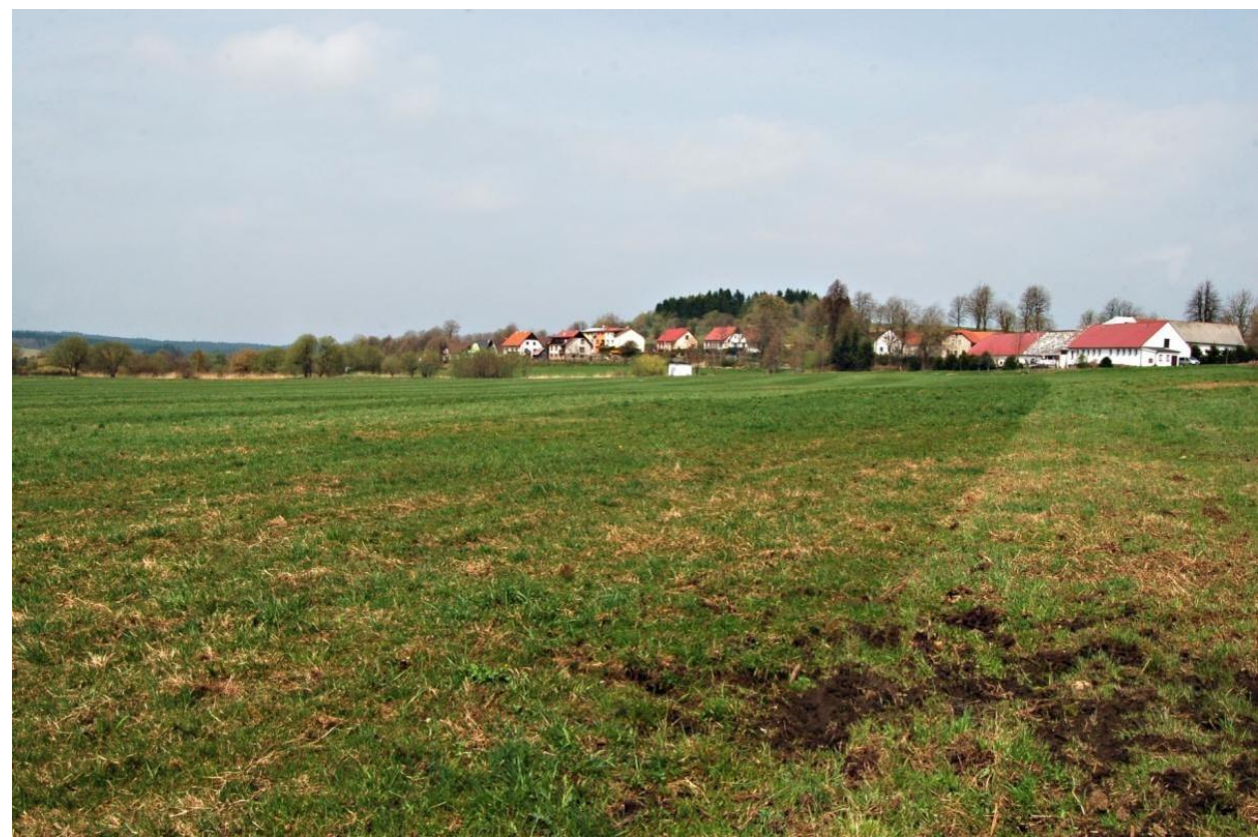


Fig. 4: Detail of a cultivated meadow with Rumex obtusifolius, photo by Josef Ptáček

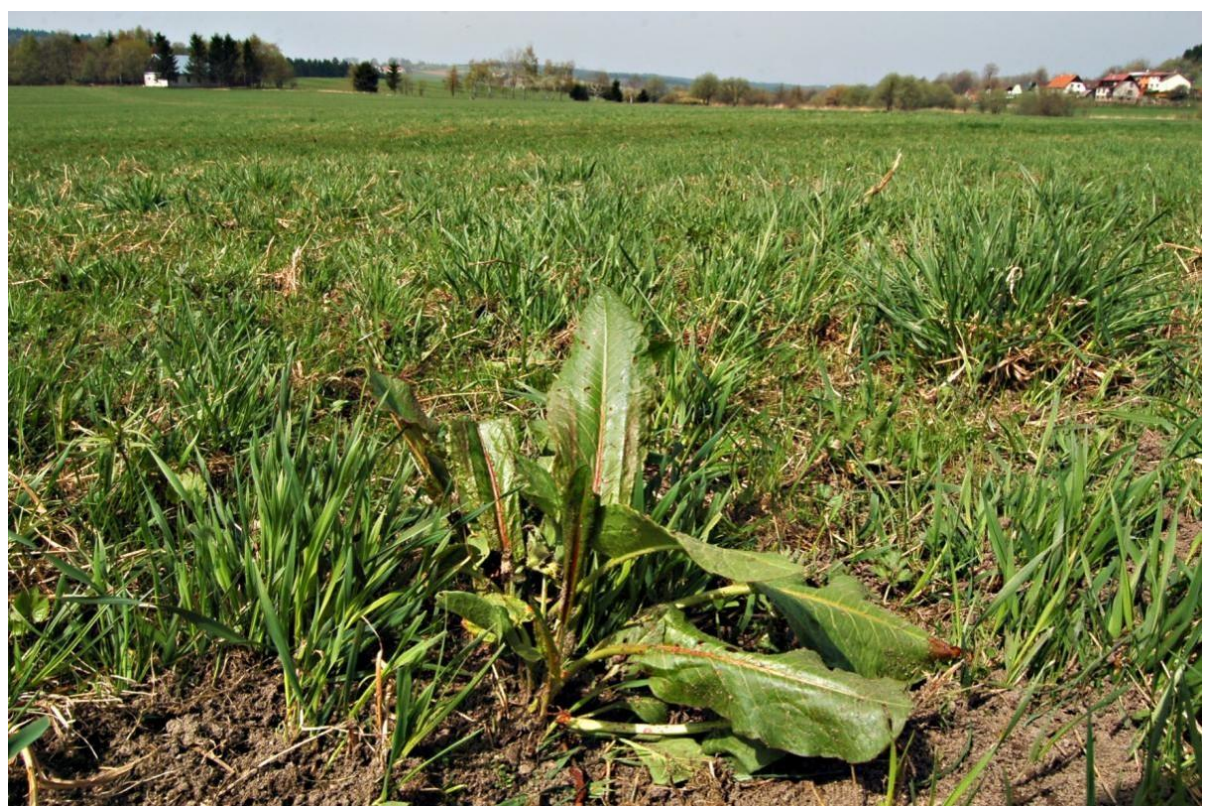

Fig. 5: The actual state of mapping of the biotope layer with shown natural biotopes, http://mapy.nature.cz/

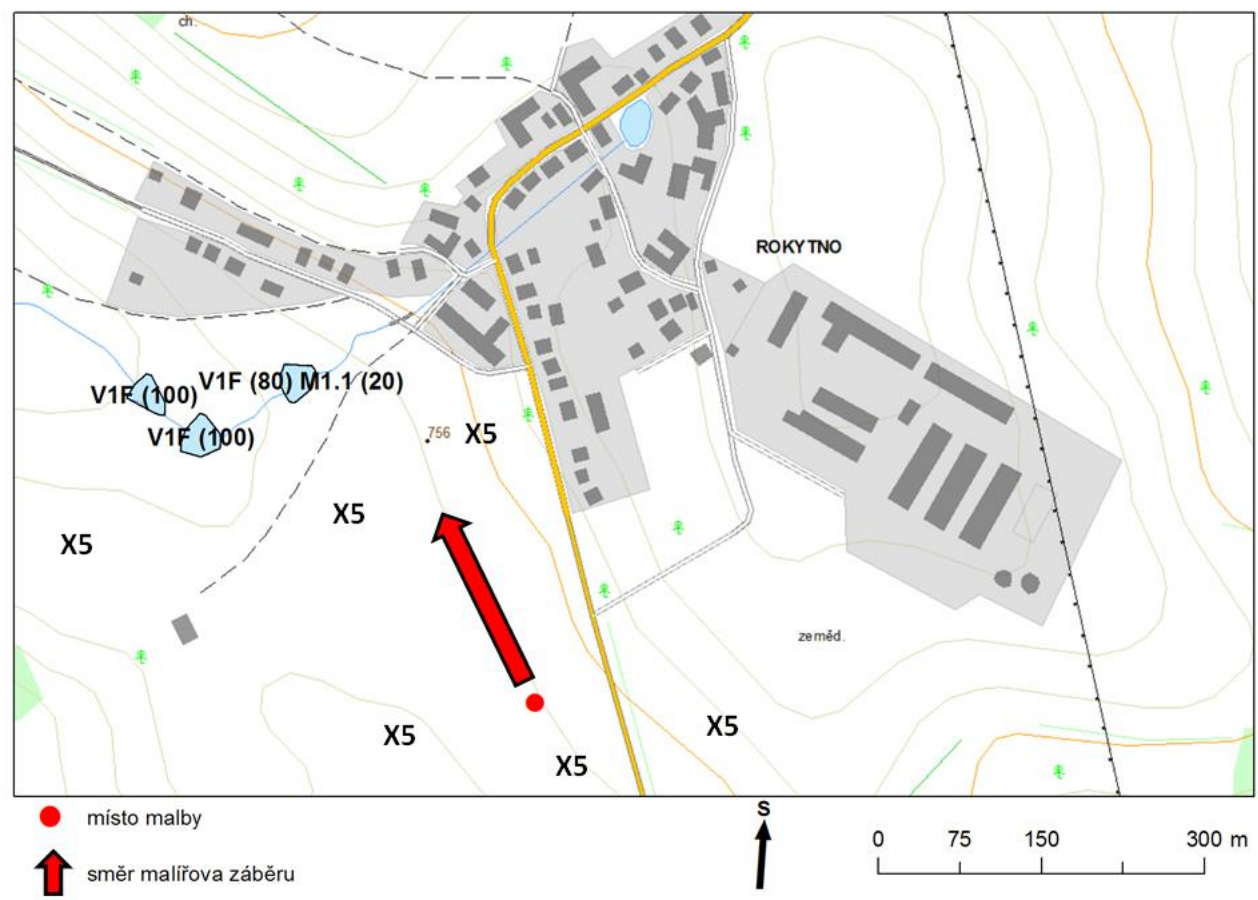




\section{CONCLUSIONS}

So far we managed to identify the accurate locality of approximately 80 artworks in the current landscape. Based on their landscape-ecological interpretation it is possible to reach the following preliminary conclusions:

1) The painters started discovering the harmonious cultural landscape following the romantic period when they used to focus on wild mountain scenes of the near-natural landscape. Within the territory of the Czech Republic, the most frequent locations of paintings include The Bohemian-Moravian Highlands with the Iron Mountains, The area known as Podorličí, The South-Bohemian Basins, The surrounding area of the Thaya River, Šumava, The White Carpathians (the so called Moravské Slovácko) and The Beskidy Mountains (Valašsko).

2) Not even in the single case it was possible to find the current state of the landscape that would be identical with its representation in the painting. Most changes include those of vegetation cover and new construction. The characterising marks of the landscape often disappeared. These included small heaths, pockets of thyme and non-ruderalised wetlands. There is more bank vegetation; however, that usually only includes regulated streams. Despite the fact that more permanent grassy vegetation can be found in the foothills, farmland is almost non-existent. The typical grazed landscape has been afforested mainly on barren rocky and gravelly river banks. Formerly grassy water meadows have been turned into farmland. There are more linear features and ruderal vegetation also increased.

3) The ecological and aesthetical value of a landscape complement each other. Landscape deprived of species diversity and their natural and near-natural communities is of a less quality from the aesthetic point of view.

4) Various understanding and feelings occur when a landscape is observed from a distance (The car driver point of view) or closely (the rambler point of view). While a glance from a distance gives the impression that the picturesque landscape mosaic remains preserved the way it used to be depicted in the comparison landscape paintings, a detailed focus reveals species decrease. The attractive original species (recognisable marks of the landscape) often decreased in favour of non-desirable and competitive ruderal species. The enjoyment of landscape beauty decreased, too, for this reason.

\section{ACKNOWLEDGEMENTS}

The contribution was created within the institutional support of the Institute of Geonics AV ČR, v.v.i., RVO:68145535."

\section{REFERENCES}

Anonymus (1997). La Route des Peintres en Cornouaille 1850-1950. Achevé d'imprimer chez Michel ARCHANT, Imprimeur à Briec-de-l'Odet, $130 \mathrm{~s}$.

Čičo, M., ed. (2014). Dve krajiny. Obraz Slovenska: 19. storočie $\times$ súčasnost'. Slovenská národná galéria, Bratislava, $239 \mathrm{~s}$. 
Dejmal, I. (2001). Česká krajina od uklizenosti $k$ vyklizenosti a zpustnutí. Leták výstavy fotografií a obrazů „Tvář naší země - krajina domova“. Správa Pražského hradu, Česká komora architektů a Společnost pro trvale udržitelný život, Praha, 1-3.

Dvořák, F. (1954). Antonín Chittussi. Státní nakladatelství krásné literatury, hudby a umění, Praha, 97 s.

Frecer, J., ed. (2009). Podyjí ve sbírce Jihomoravského muzea ve Znojmě (katalog k výstavě). Jihomoravské muzeum, Znojmo, $112 \mathrm{~s}$.

Chytrý, M., Kučera, T., Kočí, M. (2001). Katalog biotopů České republiky. Agentura ochrany př́rody a krajiny ČR, Praha, 304 s.

Kafka, B. (1956). Josef Jambor. Krajské nakladatelství Havlíčkův Brod, 16 s + obrazová př́loha.

Lacina, J. (2009). Reflexe české krajiny ve výtvarném umění z pohledu krajinného ekologa. In: Hrnčiarová, T., Mackovčin, P., Zvara, I. et al.: Atlas krajiny České republiky (s. 331). MŽP ČR Praha a VÚKOZ, v.v.i. Průhonice, oddíl 8. Krajina v umění.

Lacina, J. (2011). Poznámky krajinného ekologa k zobrazení české krajiny a př́rody ve výtvarném umění. In: Šmajs, J., (ed.): Aby Země nebyla jen hrobem (195-206). Litaratura Kultura - Př́roda. Vydala Obec spisovatelů.

Lacina, J. (2013). Vcházení do obrazů I. Veronica 27:4, 27-29.

Lacina, J. (2014). Vcházení do obrazů II. Veronica 28, 3: 44-45.

Lacina, J., Halas, P. (2013). Využití krajinomalby v krajinné ekologii. Poster na Setkání představitelů AV ČR s představiteli Pardubického kraje a představiteli Sdružení obcí Orlicko při př́iležitosti podpisu rámcové smlouvy o spolupráci mezi AV ČR a Pardubickým krajem, 18. 10. 2013, Vila Lanna, Praha.

Lacina, J., Ptáček, J., Halas, P. (2014). Vcházení do obrazů Josefa Jambora, Josef Jambor. Výstava olejomaleb a srovnávacích fotografíi. 1.3.-27.4. 2014, Galerie Jamborův dům, Tišnov.

Lacina, J., Ptáček, J., Halas, P. (2015). Vcházení do obrazů z pohledu krajinného ekologa. Výstava olejomaleb a srovnávacích fotografíi. 29.1.-24.5. 2015, Horácká galerie, Nové Město na Moravě.

Machotka, P. (2014). Cézanne: krajina jako umění. 1. české vyd. Řevnice: Arbor vitae, 223s.

Martinec, P. et al. (2006). Vliv ukončeni hlubinné těžby uhlí na životní prostředí. Pro Ústav geoniky AV ČR vydalo nakladatelství Anagram s. r. o., Ostrava, 128 s.

Prahl, R. (2012). Antonín Chittussi (1847-1891). Region a svět. Východočeská galerie, Pardubice, $64 \mathrm{~s}$.

Zlatník, A. (1963). Die Vegetationsstufen und deren Indikation durch Pflanzenarten am Beispiel der Wälder der ČSSR. Praha. Preslia, 35: 31-51. 